\title{
EDUKASI PENYEDIAAN SARANA AIR BERSIH UNTUK MENUNJANG PENERAPAN POLA HYGIENE PADA KESEHATAN IBU DAN ANAK SECARA HOLISTIC DI ERA GAWAT DARURAT COVID 19
}

\author{
Heri Shatriadi ${ }^{1}$, Renny Triwijayanti ${ }^{2}$, Renda Natalina Pratama ${ }^{3}$, Maya Indah Eka Putri ${ }^{4}$, \\ Muhammad Fauzi \\ 1,2,3 Dosen IKesT Muhammadiyah Palembang \\ ${ }^{4}$ Mahasiswa Prodi D III Kebidanan IKesT Muhammadiyah Palembang \\ ${ }^{5}$ Mahasiswa Prodi D III Kesling IKesT Muhammadiyah Palembang \\ Email Koresnpondensi : renda7714@gmail.com,
}

\begin{abstract}
ABSTRAK
COVID-19 adalah penyakit yang disebabkan oleh virus SARS-CoV-2 yang merupakan bagian dari tipe virus Corona. Virus ini bisa menular jika kita kontak langsung dengan orang yang terinfeksi atau dengan cairan yang dikeluarkannya oleh saat batuk dan bersin. Virus dapat berpindah ke tubuh kita, bila tanpa sengaja kita menyentuh benda-benda tersebut lalu menyentuh wajah (mata, mulut, dan hidung) dengan tangan yang telah terkontaminasi. Mencuci tangan sesering mungkin dan dengan cara yang tepat (setidaknya selama 40 detik) adalah salah satu langkah paling penting untuk mencegah infeksi COVID-19. Cuci Tangan Pakai Sabun (CTPS) jauh lebih efektif membunuh kuman, bakteri, dan virus dibandingkan dengan mencuci tangan dengan air saja. Upaya yang dilakukan pemerintah dalam merespon situasi yang terjadi sebagai dampak dari pandemi COVID-19 yaitu dengan menyediakan saran cuci tangan pakai sabun diberbagai tempat publik. Tujuan dari kegiatan pengabdian kepada masyarakat ini adalah untuk memberikan Edukasi Penyediaan Sarana Air Bersih untuk menunjang Penerapan Pola Hygiene Pada Kesehatan Ibu dan Anak Secara Holistic di Era Gawat Darurat Covid 19". Hasil pendidikan kesehatan yang telah dilakukan pada tanggal 8-12 Maret 2021 di rumah responden di Kabupaten Musi Banyuasin tentang edukasi Penyediaan Sarana Air Bersih untuk Menunjang Penerapan Pola Hiegiene Pada Kesehatan Ibu dan Anak Secara Holistic di Era Gawat Darurat Covid 19 didapatkan hasil adanya peningkatan pengetahuan masyarakat tentang cara mencuci tangan dan penyediaan sarana cuci tangan yaitu dari 68,05\% menjadi 90,28\%.
\end{abstract}

Kata kunci: Edukasi, Sarana Air Bersih, Cuci Tangan, Pola Hygiene

\section{EDUCATION FOR THE PROVISION OF CLEAN WATER FACILITIES TO SUPPORT THE APPLICATION HYGIENE PATTERNS IN HOLISTIC HEALTH OF MOTHERS AND CHILDREN IN THE EMERGENCY ERA COVID 19}

\begin{abstract}
COVID-19 is a disease caused by the SARS-CoV-2 virus which is part of the Corona virus type. This virus can be transmitted if we come into direct contact with an infected person or with the fluids released by coughing and sneezing. Viruses can be transferred to our bodies, if we accidentally touch these objects and then touch the face (eyes, mouth, and nose) with contaminated hands. Washing your hands frequently and in an appropriate manner (for at least 40 seconds) is one of the most important steps to prevent COVID-19 infection. Handwashing with soap (CTPS) is much more effective in killing germs, bacteria, and viruses than washing hands with water alone. Efforts made by the government in responding to the situation that occurred as a result of the COVID-19 pandemic, namely by providing advice on washing hands with soap in various public places. The purpose of this community service activity is to provide Education on the Provision of Clean Water Facilities to Support the Implementation of Hygiene Patterns in Holistic Maternal and Child Health in the Covid 19 Emergency Era. The results of the health education carried out on March 8-12 2021 at the respondent's house in Musi Banyuasin Regency regarding education on the Provision of Clean Water Facilities to Support the Implementation of Hygiene Patterns in Holistic Maternal and Child Health in the Covid 19 Emergency Era, the results showed that there was an increase in public knowledge on how to wash hands and the provision of hand washing facilities, namely from $68.05 \%$ to $90.28 \%$.
\end{abstract}

Keywords: Education, Clean Water Facilities, Hand Washing, Hygiene Pattern 


\section{PENDAHULUAN}

Tantangan terkini yang harus dihadapi dunia adalah adanya pandemi Covid-19. Covid-19 menjadi momok yang menghantui berbagai bangsa, tidak terkecuali bangsa Indonesia. Covid-19 mempengaruhi secara signifikan hampir seluruh perikehidupan. Perekonomian bangsa-bangsa menjadi lebih rapuh. Beragam sektor terdampak. Sedikit sektor yang dapat survive dalam pandemi Covid-19. Sektor terkait kesehatan termasuk yang mendapatkan tantangan dan peluang secara sekaligus. Sektor air bersih yang erat kaitannya dengan kesehatan masyarakat termasuk yang mendapatkan tantangan dan peluang sekaligus.

Hingga saat ini, pandemi Covid-19 belum menunjukan tanda-tanda berakhir dalam waktu dekat, meski di beberapa negara jumlah pasien terinfeksi perharinya telah mengalami penurunan, di Indonesia ternyata kasus tiap hari semakin meningkat. Pada pertengahan Februari 2021 saat ini, kasus yang terkonfirmasi positif Covid-19 secara global adalah sebanyak lebih dari 106 juta jiwa, sedangkan di Indonesia sebanyak lebih dari 1,1 juta jiwa (Covid, 2021). Berbagai upaya sudah dilaksanakan pemerintah dalam mengatasi pandemi ini, namun semua pihak untuk bekerja sama, tetap waspada, menerapkan aturan jaga jarak, hingga belum diperbolehkan berkumpul dalam jumlah besar. Semua aturan itu diterapkan tentu untuk mencegah terjadinya penyebaran virus corona.

COVID-19 adalah penyakit yang disebabkan oleh virus SARS-CoV-2 yang merupakan bagian dari tipe virus Corona. Virus ini bisa menular jika kita kontak langsung dengan orang yang terinfeksi atau dengan cairan yang dikeluarkannya oleh saat batuk dan bersin. Virus dapat berpindah ke tubuh kita, bila tanpa sengaja kita menyentuh benda-benda tersebut lalu menyentuh wajah (mata, mulut, dan hidung) dengan tangan yang telah terkontaminasi. Mencuci tangan sesering mungkin dan dengan cara yang tepat (setidaknya selama 40 detik) adalah salah satu langkah paling penting untuk mencegah infeksi COVID-19. Cuci Tangan Pakai Sabun (CTPS) jauh lebih efektif membunuh kuman, bakteri, dan virus dibandingkan dengan mencuci tangan dengan air saja. Sabun dapat dengan mudah menghancurkan membran lipid COVID-19, membuat virus COVID-19 tidak aktif.

Cuci tangan pakai sabun terbukti efektif mencegah penularan virus corona karena tangan yang bersih setelah dicuci pakai sabun dapat mengurangi risiko masuknya virus ke dalam tubuh mengingat: tanpa disadari orang sering menyentuh mata, hidung, dan mulut sehingga dapat menyebabkan virus masuk ke dalam tubuh, virus corona dari tangan yang tidak dicuci dapat berpindah ke benda lain atau permukaan yang sering disentuh seperti pegangan tangga atau eskalator, gagang pintu, permukaan meja, atau mainan- sehingga menimbulkan risiko penyebaran virus kepada orang lain. Kebiasaan mencuci tangan sangat penting untuk dipraktikkan secara terus menerus agar memberikan dampak yang efektif khususnya dalam rangka pencegahan penyakit. Pada masa pandemi COVID-19 orang termotivasi untuk CTPS dengan tujuan mencegahan penularan COVID-19. Momentum ini harus dimanfaatkan untuk dapat membuat praktik CTPS menjadi suatu kebiasaan (Kemenkes, 2020).

CTPS dengan air mengalir diakui secara global sebagai salah satu perilaku kebersihan yang paling mendasar dengan dampak kesehatan yang besar. Dengan alasan ini, promosi perilaku CTPS dengan air mengalir, terutama di waktu kritis termasuk saat wabah, masih menjadi pendekatan 
utama dalam pencegahan penyakit berbasis lingkungan (diare, cacingan, typus, ISPA), dan pembiasaan hidup bersih dan sehat. Pemerintah Afrika Selatan menjadi contoh munculnya kesadaran pemangku kepentingan, kunci tentang pentingnya air bersih (untuk mencuci tangan) dalam upaya mencegah penyebaran Covid-19. Empat puluh satu ribu titik penyediaan air bersih tambahan dibangun Pemerintah Afrika Selatan di seluruh pelosok negeri agar seluruh masyarakat mendapatkan akses air bersih untuk cuci tangan. Sementara sebelumnya pemerintah relatif kurang memprioritaskan akses air bersih (Cristopher Gasson, 2020)

Terdapat dua komponen yang harus diupayakan agar dapat mempertahankan kebiasaan CTPS yaitu komponen teknis (hardware) dan non-teknis (software). Komponen hardware mencakup ketersediaan sabun, air bersih, dan sarana cuci tangan yang sesuai. Sedangkan komponen software adalah pengetahuan tentang mencuci tangan, motivasi untuk melakukannya; dan konteks sosial untuk memakai bahan yang dibutuhkan. Sabun merupakan teknologi utama untuk mencuci tangan. Sabun harus tersedia dengan biaya yang terjangkau, agar memungkinkan tiap rumah tangga untuk memilikinya. Meskipun menggunakan sabun adalah cara paling efektif untuk membersihkan tangan, seringkali tidak semua rumah tangga bisa memilikinya. Keluarga yang tergolong berpenghasilan rendah cenderung mengalokasikan uang yang dimiliki untuk membeli kebutuhan pokok lain. Sekalipun telah membeli sabun untuk mencuci pakaian, kerap kali sabun itu tidak digunakan untuk mencuci tangan. Kebiasaan CTPS akan sulit dipertahankan bila air tidak tersedia. Untuk itu, ketersediaan air bersih menjadi mutlak diperlukan dalam praktik cuci tangan. Walaupun demikian, air yang dialirkan melalui pipa bukan suatu keharusan. Air bersih yang dituangkan dari timba atau wadah lainnya juga sudah cukup.

Rekomendasi menurut WHO (2020) untuk pembuat kebijakan, otoritas kesehatan masyarakat dan petugas kesehatan, paling tidak satu sarana kebersihan tangan (baik untuk mencuci tangan pakai sabun dan air atau untuk menggosok tangan dengan alkohol) beserta dengan panduan ringkas harus ditempatkan di depan pintu masuk setiap tempat umum (termasuk sekolah, fasilitas kesehatan, masjid, gereja) atau bangunan komersial (seperti pusat perbelanjaan, pasar) untuk memungkinkan semua orang mempraktikkan kebersihan tangan sebelum masuk dan ketika meninggalkannya. (World Health Organization, 2020).

Proporsi perilaku cuci tangan dengan benar (yaitu cuci tangan pakai sabun sebelum menyiapkan makananan, setiap kali tangan kotor, setelah buang air, setelah menceboki bayi/anak, setelah menggunakan pestisida/insektisida, sebelum menyusui bayi dan sebelum makan) di Indonesia pada tahun 2018 sebesar 49,8\%. Presentase tersebut meningkat daripada data sebelumnya tahun 2007 sebesar 23,2\% dan tahun 2013 sebesar 47\% (Riskesdas, 2018). Sedangkan data statistic yang didapatkan untuk proporsi populasi yang memiliki fasilitas cuci tangan dengan sabun dan air mengalir di Indonesia didapatkan tahun 2018 sejumlah 78,87\% dan tahun 2019 sebesar 76,07 \% hal ini menunjukan bahwa terjadi penurunan proporsi populasi yang memiliki fasilitas cuci tangan pakai sabun (Badan Pusat Statistik, 2019). 


\section{MASALAH}

Praktik Cuci Tangan Pakai Sabun (CTPS) dengan air bersih mengalir menjadi cara efektif untuk mencegah terjadinya penyebaran virus Covid-19 melalui permukaan. Kebutuhan tersedianya fasilitas cuci tangan dengan sabun sangat diharapkan oleh masyarakat terutama dalam kondisi pandemic covid19 saat ini. Jumlah dan kegunaan sarana kebersihan tangan harus disesuaikan dengan jenisnya (misalnya anak-anak, orang tua, mereka yang mobilitasnya terbatas) dan jumlah pengguna untuk mendorong penggunaan dan mengurangi waktu tunggu dengan lebih baik. Kebersihan tangan setiap kali beraktivitas harus dipromosikan berulang kali untuk menjadi bagian dari perilaku hidup bersih sehari-hari di keluarga dan masyarakat. Berdasarkan data kebutuhan di atas dan hasil riset dimana terjadi penurunan proporsi populasi yang memiliki fasilitas cuci tangan dengan sabun dan air mengalir di Indonesia, maka Institut Ilmu Kesehatan dan Teknologi Muhammadiyah Palembang turut berperan melalui kegiatan pengabdian masyarakat oleh civitas akademikanya dengan tema "Edukasi Penyediaan Sarana Air Bersih untuk menunjang Penerapan Pola Hygiene Pada Kesehatan Ibu dan Anak Secara Holistic di Era Gawat Darurat Covid 19"

\section{METODE PELAKSANAAN}

Kegiatan pendidikan kesehatan ini dilakukan melalui 4 tahap yaitu tahap perizinan, persiapan, pelaksanaan, dan evaluasi.

\section{Perizinan}

Perizinan pengabdian masyarakat tentang Edukasi penyediaan sarana air bersih untuk menunjang penerapan pola hygiene pada kesehatan ibu dan anak secara holistic di era gawat darurat covid 19 dilakukan setelah menentukan tempat, sasaran penyuluhan yaitu di Kabupaten Musi Banyuasin, perizinan dilakukan kepada kepala desa setempat.

\section{Persiapan kegiatan}

Persiapan pengabdian masyarakat dimulai dengan memastikan sasaran khususnya dalam hal jumlah peserta. Tempat dan media dipersiapkan sesuai dengan kebutuhan serta antisipasi kemungkinan masalah yang terjadi. Tempat pelaksanaan pendidikan kesehatan adalah rumah responden masingmasing dan media penyuluhan yang dipersiapkan untuk mempermudah proses pemahaman sasaran sehingga tujuan kegiatan dapat tercapai secara optimal yaitu berupa video dan instrument kuesioner pre dan posttest.

\section{Kegiatan Pelaksanaan}

Kegiatan pendidikan kesehatan ini dilakukan pada tanggal 8-12 Maret 2021 bertempat di rumah masyarakat yang menjadi responden di Kabupaten Musi Banyuasin. Tahap pelaksanaan kegiatan meliputi: Pengisian daftar hadir, Pembukaan, Pembagian kuisioner pretest melalui link https://forms.gle/snWtpvAc8Nu9kpzY8, Penyampaian sosialisasi dan pemutaran video, Diskusi/ Tanya jawab, Pembagian kuisioner posttest, Penutup 


\section{Evaluasi Kegiatan}

Evaluasi dilakukan untuk mengetahui efektifitas kegiatan pendidikan kesehatan. Evaluasi ini dilakukan dengan pengisian kuisioner pretest dan postest tentang edukasi Penyediaan Sarana Air Bersih untuk Menunjang Penerapan Pola Hiegiene Pada Kesehatan Ibu dan Anak Secara Holistic di Era Gawat Darurat Covid 19" sebagai upaya pencegahan Covid-19. Dari hasil evaluasi awal didapatkan hasil masih rendahnya pengetahuan masyarakat tentang mencuci tangan menggunakan sabun sebesar 54.17\%, masih ada masyarakat yang belum mencuci tangan dengan benar sebesar 16,67\% dan masyarakat yang belum tahu cara pembuatan alat cuci tangan sederhana sebesar $66,67 \%$. Pengetahuan mengenai edukasi Penyediaan Sarana Air Bersih untuk Menunjang Penerapan Pola Hiegiene Pada Kesehatan Ibu dan Anak Secara Holistic di Era Gawat Darurat Covid 19 sebagai upaya pencegahan Covid-19 dengan rata-rata sebesar $68.05 \%$.

\section{PEMBAHASAN}

COVID-19 atau Virus Corona merupakan penyakit baru yang penyebarannya sangat cepat dan telah menjadi pandemi di Indonesia saat ini (Susilo, et al, 2020; Syafrida \& Hartati, 2020).(Syafrida., \& Hartati, 2020) WHO (2020) menjelaskan berdasarkan bukti bahwa penyebaran COVID-19 melalui air liur, sekresi saluran pernapasan atau melalui cairan saluran nafas yang terjadi ketika melakukan kontak langsung, tidak langsung maupun intens dengan orang yang terinfeksi COVID-19. Adapun kegiatan yang memungkinkan individu terpapar droplet ialah ketika seseorang berbicara, bersin, batuk, atau menyanyi.(World Health Organization, 2020)

Rekomendasi standar untuk meredam transmisi infeksi adalah sering cuci tangan menggunakan sabun dan air mengalir, menerapkan etika batuk dan bersin, memakai masker, menghindari kontak langsung dengan ternak atau hewan liar serta menghindari kontak erat dengan mereka yang menunjukkan gejala batuk dan bersin (Siregar, R., Gulo, A. R. B., \& Sinurat, 2020). Akibatnya, kegiatan yang masih harus dilakukan dalam lingkup publik seperti pelayanan kesehatan dan pemenuhan kebutuhan pokok mendapatkan himbauan untuk menerapkan protokol kesehatan di antaranya rajin cuci tangan dan jaga jarak antar individu secara fisik (Supriatun, E., Insani, U., \& Ni'mah, 2020).

Masyarakat Indonesia sebagian besar kurang mengetahui bagaimana mencuci tangan dengan benar. Hal itu ditunjukkan dengan masih banyaknya penyebaran penyakit yang ditransmisikan lewat tangan yang kurang higienis, seperti diare, flu, batuk, cacingan (Hasibuan, P. A. Z., Nasution, A., Rosidah, Reveny, J., 2020). Pada kenyataannya, sebagian besar masyarakat tidak menjalankan langkah mencuci tangan dengan baik, yang meliputi membasahi kedua tangan dengan air bersih, menggunakan sabun, menggosok telapak tangan yang satu ke telapak tangan lainnya, gosok punggung tangan dan sela jari, gosok telapak tangan dan sela jari dengan posisi saling bertautan, gosok punggung jari ke telapak tangan dengan posisi jari saling bertautan, genggam dan basuh ibu jari dengan posisi memutar, gosok bagian ujung jari ke telapak tangan agar bagian kuku terkena sabun, cuci dengan air bersih mengalir, keringkan dnegan lap seklai pakai atau tisu, bersihkan pemutar keran air dengan lap sekali pakai atai 
tisu (Kemenkes RI, 2020) Selain itu juga masih dijumpai kurangnya sarana atau fasilitas cuci tangan yang memadai serta belum cukupnya edukasi tentang mencuci tangan yang baik dan benar (Sari, T. W., Mubarak, H., \& Ningrum, 2020). Selain itu menurut Dewantoro, 2020 penyediaan sarana cuci tangan nirsentuh sebagai sarana edukatif bagi masyarakat serta penyediaan sarana cuci tangan sederhana .(Dewantoro \& Setyawijaya, 2020)(Fatin Hanifa et al., 2020).

Kegiatan Pengabdian masyarakat ini dilakukan dengan memberikan edukasi Penyediaan Sarana Air Bersih untuk Menunjang Penerapan Pola Hiegiene Pada Kesehatan Ibu dan Anak Secara Holistic di Era Gawat Darurat Covid 19. Pada kegiatan ini masyarakat di berikan informasi materi mencuci tangan dan penyediaan saran air bersih dengan pembuatan alar cuci tangan sederhana. Kegiatan ini dilaksanakan untuk meningkatkan derajat kesehatan serta mencegah penyebaran virus Covid-19.

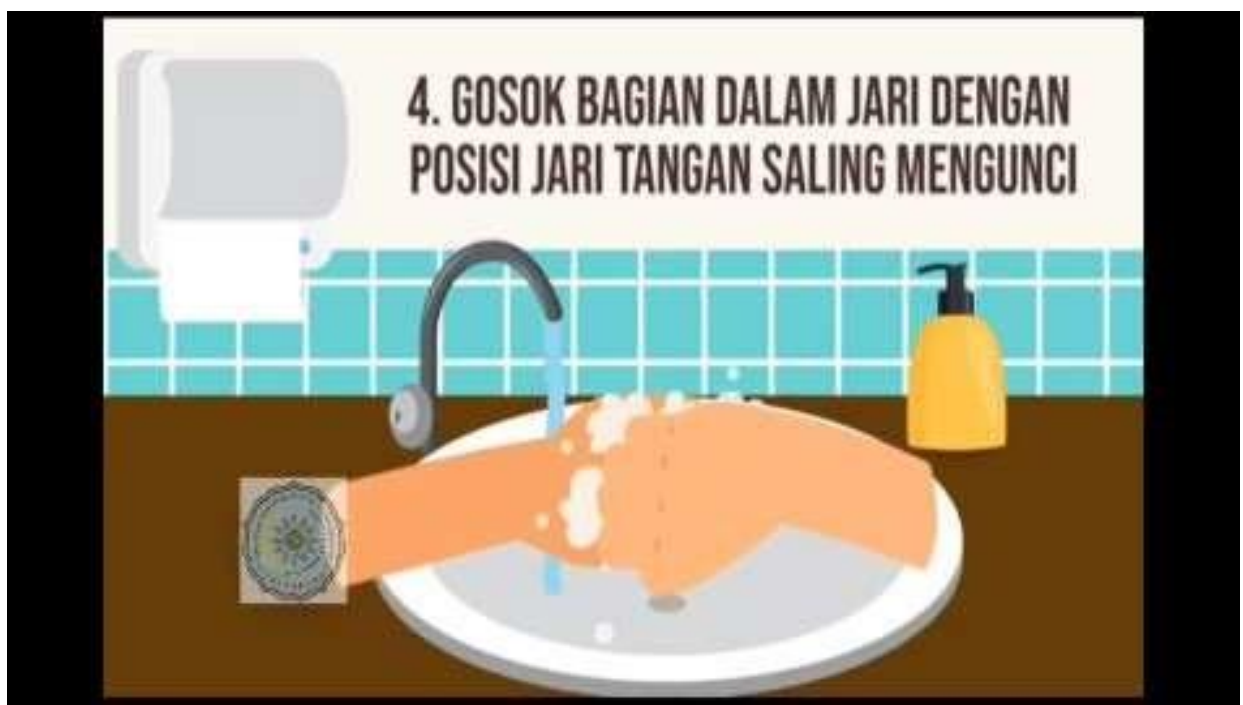

Gambar 1

Video Cara Mencuci Tangan (upload di Youtube)

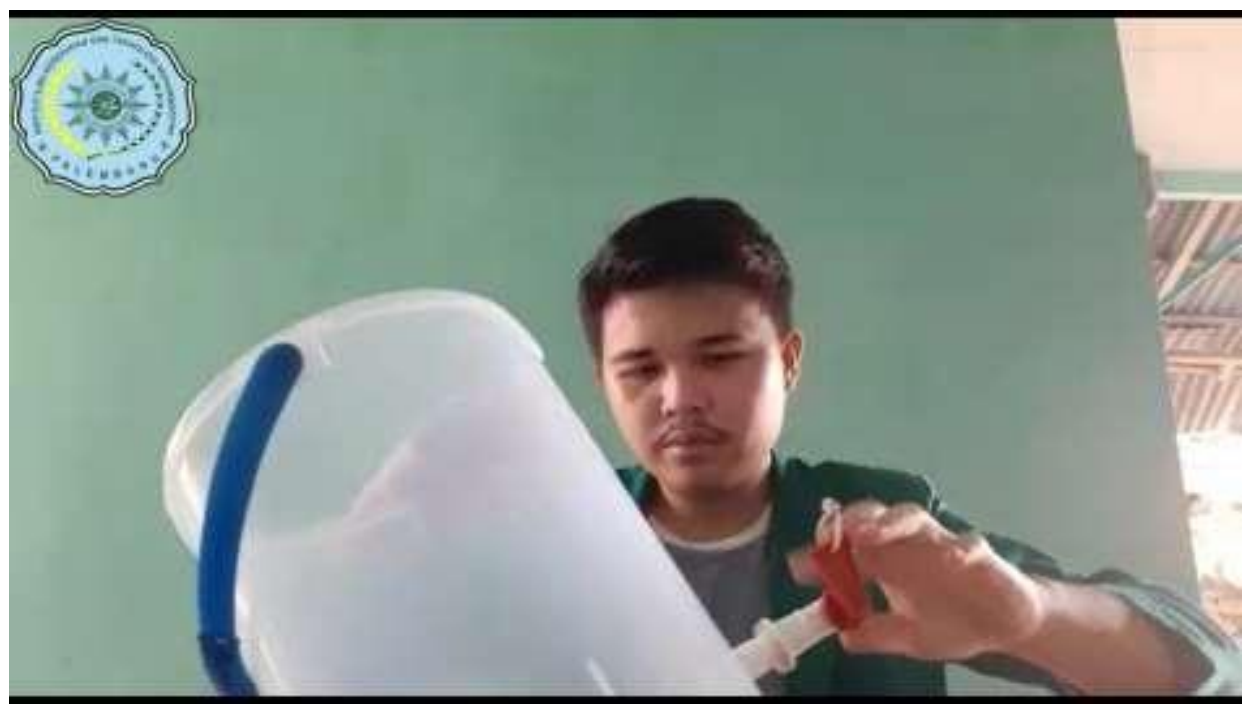

Gambar 2

Video Cara Membuat Alat Cuci Tangan Sederhana (upload di Youtube) 
Hasil kegiatan pengabdian masyarakat edukasi Penyediaan Sarana Air Bersih untuk Menunjang Penerapan Pola Hiegiene Pada Kesehatan Ibu dan Anak Secara Holistic di Era Gawat Darurat Covid 19. Setelah dilakukan Pendidikan Kesehatan melalui video melalui link, dilakukan evalusi dengan mengajukan beberapa pertanyaan kepada responden yaitu, apakah responden mampu menunjukan cara mencuci tangan dengan benar, apakah responden selama ini mencuci tangan menggunakan sabun, dan apakah responden tahu cara membuat alat cuci tangan sederhana, pertanyaan berupa checklist "ya" dan "tidak". Dari instrument pertanyaan ini didapatkan peningkatan dari $68.05 \%$ menjadi $90,28 \%$.

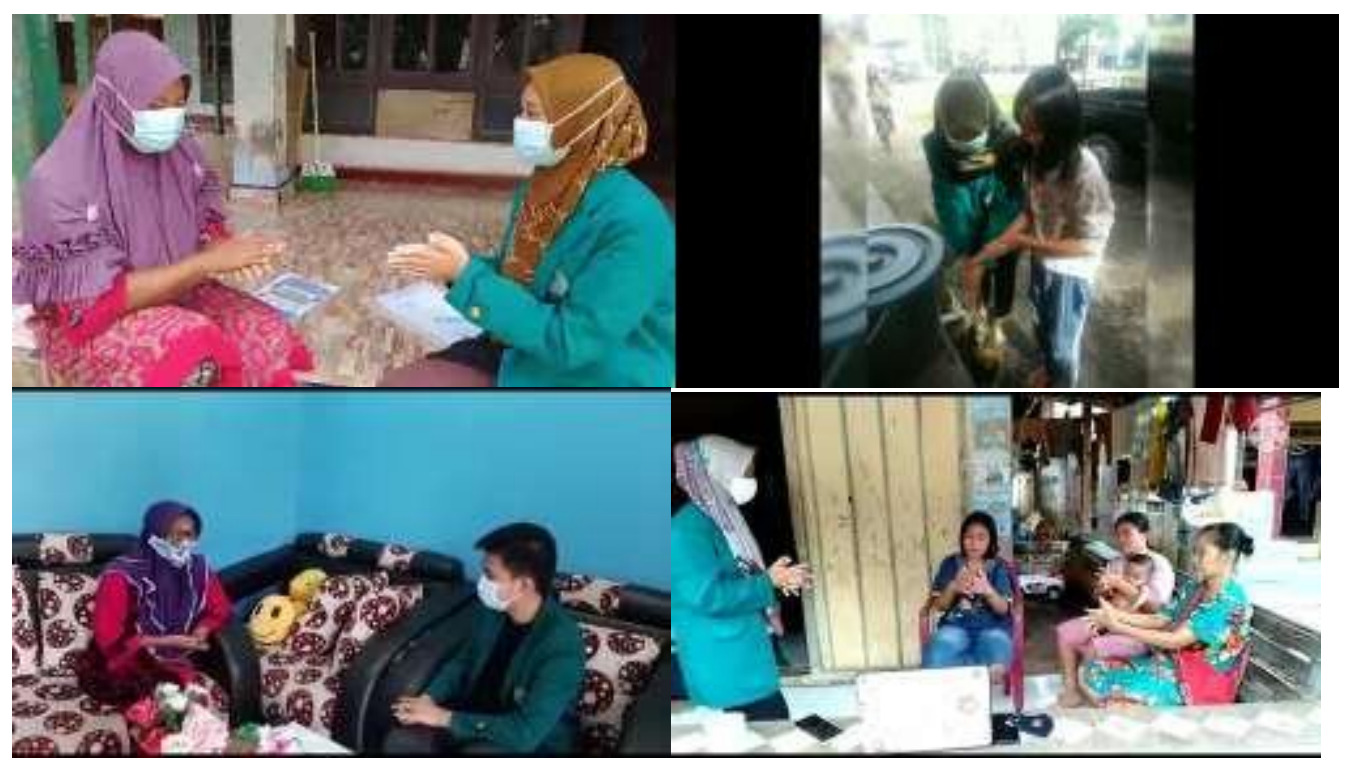

Gambar 3

Pelaksanaan Edukasi Cara Mencuci Tangan yang Benar

Menurut Sinaga, dkk (2020), mayoritas masyarakat masih belum mempunyai pemahaman yang baik mengenai pentingnya perilaku mencuci tangan dengan menggunakan sabun, cara yang benar mencuci tangan dan kapan saja diperlukan cuci tangan pakai sabun. Serta sedikitnya kesadaran masyarakat untuk melakukan kebiasaan cuci tangan menggunakan sabun khususnya saat masalah pandemic Covid 19 seperti sekarang ini Salah satu upaya yang dilakukan untuk membantu pemerintah dan meningkatkan kesehatan masyarakat dengan mengurangi penularan virus covid-19 adalah dengan dilakukanya penyuluhan dan sosialisasi Cuci Tangan menggunakan Sabun.

\section{KESIMPULAN}

Dosen membina hubungan baik dan kerjasama dengan masyarakat, dosen mendapatkan situasi nyata dan aktual di masyarakat yang berhubungan dengan masalah kesehatan, dosen dapat menerapkan disiplin ilmu untuk membantu meningkatkan derajat kesehatan masyarakat khusus pada upaya promotif dan preventif, adanya peningkatan pengetahuan masyarakat tentang cara mencuci tangan dan penyediaan sarana cuci tangan yaitu dari 68,05\% menjadi 90,28\%. 


\section{UCAPAN TERIMA KASIH}

Ucapan terima kasih kepada rektor IKesT Muhammadiyah Palembang beserta jajarannya, LP2MI IKesT Muhammadiyah Palembang, Program studi DIII Kebidanan IKesT Muhammadiyah Palembang, Bupati dan seluruh warga Kabupaten Musi Banyuasin yang telah berpartisipasi aktif dalam kegiatan ini

\section{DAFTAR PUSTAKA}

Covid, S. (2021). Data Sebaran Situasi virus Covid-19 di Indonesia. Diakses pada https://www.covid19.go.id/ tanggal 10 Februari 2021.

Cristopher Gasson. (2020). Using the COVID-19 Crisis for A Better Water Sector, article published

on https://www.globalwaterintel.com/news/2020/14/using-the-covid-19-crisis- for-abetterwatersector,. Diakses 9 Mei 2020.

Dewantoro, G., \& Setyawijaya, I. J. I. A. F. Y. H. (2020). Rancang Bangun Alat

Cuci Tangan Nirsentuh sebagai Sarana. Pengabdian Masyarakat, 01(2), 203-214. Retrieved from https://ejournal.uksw.edu/jms/article/view/4296

Fatin Hanifa, Rahmah, A. H., Damayana, F., Khan, H. T., Fadilah, I., Lestari, M.D., \& Sartika, Y. (2020). Pembuatan Cuci Tangan Sederhana Pada Masyarakat Daerah Zona Merah Sebagai Langkah Pencegahan Penyebaran Covid-19. BERNAS: Jurnal Pengabdian Kepada Masyarakat, 1(4), 640-648. https://doi.org/10.31949/jb.v1i4.524

Hasibuan, P. A. Z., Nasution, A., Rosidah, Reveny, J., \& M. (2020). Penyuluhan langkah cuci tangan di SMAN 1 Delitua, Kabupaten Deli Serdang, Sumatera Utara. Jurnal Abdimas Kesehatan Perintis, $1(2), 40-42$.

Kemenkes RI. (2020). Panduan Cuci Tangan Pakai Sabun. Jurnal Kesehatan, 20. Sari, T. W., Mubarak, H., \& Ningrum, P. (2020). Edukasi kesehatan protokol pencegahan COVID-19 dan penyerahan bantuan sembako di panti asuhan AsSalam Kota Pekanbaru. Jurnal Abdidas, 1(5), 436-441.

Siregar, R., Gulo, A. R. B., \& Sinurat, L. R. E. (2020). Edukasi tentang upaya pencegahan covid-19 pada masyarakat di pasar Sukaramai Kecamatan Medan Area tahun 2020. Jurnal Abdimas Mutiara, 1(2), 191-198.

Supriatun, E., Insani, U., \& Ni'mah, J. (2020). Edukasi pencegahan penularan COVID 19 di rumah yatim Kota Tegal. JABI: Jurnal Abdimas Bhakti Indonesia, 1(2), 1-14. Syafrida., \& Hartati, R. (2020). Bersama melawan virus covid 19 di Indonesia. Jurnal Social \& Budaya Syar'I, 7(6), 495-508, DOI:10.15408/Sjsbs.V7i6.15325.

World Health Organization. (2020). Clinical management of severe acute respiratory infection when novel coronavirus (nCoV) infection is suspected. Geneva: World Health Organization. 